\title{
Compared effects of competition by grasses (Graminoids) and broom (Cytisus scoparius) on growth and functional traits of beech saplings (Fagus sylvatica)
}

\author{
Damien ProvendieR ${ }^{1,2}$, Philippe BALANDIER ${ }^{1,3 *}$ \\ ${ }^{1}$ Cemagref, Forest Ecosystem Research Unit, Domaine des Barres, 45290 Nogent-sur-Vernisson, France \\ ${ }^{2}$ Present address: 25 bis rue Tour-d'Auvergne, 44200 Nantes, France \\ ${ }^{3}$ INRA, UMR547 PIAF, 63100 Clermont-Ferrand, France
}

(Received 12 October 2007; accepted 2 April 2008)

\begin{abstract}
-
- The effect of two weeds (grasses and broom, Cytisus scoparius) competition on the growth and functional traits of European beech saplings (Fagus sylvatica) was investigated in an experimental plantation in the French Massif central.

- We hypothesized that grasses would have a much more harmful effect than broom on beech growth through strong competition for soil water and nitrogen.

- A randomized block design was used with three separate blocks, each possessing three types of vegetation; grasses (mainly Agrostis capillaris, Holcus mollis and H. lanatus), broom, and bare soil as a control.

- Two years after plantation beech sapling growth was significantly greater in bare soil than with competition from grasses, and was intermediate on broom. Growth was positively correlated with beech leaf nitrogen content $\left(\mathrm{N}_{\mathrm{m}}\right)$ and xylem water potential $\left(\Psi_{\mathrm{x}}\right)$. $\mathrm{N}$ and $\Psi_{\mathrm{x}}$ were dependent, with nitrogen uptake probably decreasing with increasing drought. There was no clear correlation between growth and light transmitted $10 \mathrm{~cm}$ below the apex of the saplings.

- Beech leaf mass on an area basis (LMA) was correlated with the three resource variables (water, nitrogen and light) and with growth, confirming that $L M A$ is a sensitive functional trait integrating the degree of stress experienced by the saplings.

- The results suggest that broom is less competitive than grasses and, if properly managed on a sufficiently well-watered site, can generate satisfactory conditions for beech establishment and growth.
\end{abstract}

Fagus sylvatica / Cytisus scoparius / competition / nitrogen / water

Résumé - Comparaison des effets de la compétition par les graminées (Graminoüdes) et le genêt (Cytisus scoparius) sur la croissance et les traits fonctionnels de plants de hêtre (Fagus sylvatica).

- L'effet de la compétition de deux adventices (graminées et genêt, Cytisus scoparius) sur la croissance et les traits fonctionnels de plants de hêtre européen (Fagus sylvatica) a été expérimenté dans une plantation du Massif central.

- Nous avons testé l'hypothèse selon laquelle les graminées ont un effet plus délétère que le genêt sur la croissance du hêtre à cause d'une très forte compétition pour l'eau du sol et l'azote.

- Un plan d'expérience en trois blocs complets a été utilisé, chacun possédant trois types de végétation : des graminées (principalement Agrostis capillaris, Holcus mollis and H. lanatus), du genêt et un sol nu comme témoin.

- Deux ans après la plantation, les plants de hêtre étaient significativement plus gros en sol nu par rapport à ceux subissant la compétition des graminées, ceux en présence du genêt étant intermédiaires. La croissance a été positivement reliée à la teneur en azote des feuilles $\left(\mathrm{N}_{\mathrm{m}}\right)$ ainsi qu'au potentiel hydrique de xylème $\left(\Psi_{\mathrm{x}}\right) . \mathrm{N}_{\mathrm{m}}$ et $\Psi_{\mathrm{x}}$ semblent dépendant, l'absorption d'azote diminuant avec l'augmentation de la sécheresse. Aucune corrélation significative n'a pu être mise en évidence entre la croissance des plants et la lumière transmise à $10 \mathrm{~cm}$ sous leur apex.

- La masse foliaire rapportée à sa surface $(L M A)$ a été corrélée aux trois variables correspondant aux ressources (azote, eau et lumière) et avec la croissance, confirmant que le LMA est un trait fonctionnel pertinent intégrant le degré de stress subi par les plants.

- Les résultats suggèrent que le genêt est moins compétitif que les graminées. Sur un site suffisamment pourvu en eau, il peut produire des conditions favorables à la croissance des hêtres s'il est géré correctement.

Fagus sylvatica / Cytisus scoparius / compétition / azote / eau

\section{INTRODUCTION}

In young forest plantations, competing vegetation is often an important constraint for the growth and survival of crop tree seedlings or saplings (Balandier et al., 2006; Wagner et al., 2006). Trees and vegetation compete for main resources, namely water, nutrients and light (Löf, 2000; Nambiar and

* Corresponding author: philippe.balandier@cemagref.fr
Sand, 1993; Wang et al., 2000). Vegetation around seedlings is therefore generally controlled using herbicides. However, in the face of increasing environmental and social pressure in a multipurpose silviculture context, forestry practices are evolving towards less use of chemical herbicides in forests, and more research on alternative affordable methods of vegetation management (Coll et al., 2007; Lamhaledi et al., 1998; Schütz, 2004; Willoughby, 1999). Sounder practices need a 
classification of actual weed competitiveness in forests, which means determining how each vegetation type alters resource availability, and how crop trees respond to these changes (Goldberg, 1996). Competition varies greatly depending on crop tree species and vegetation composition among other factors (Coll et al., 2003; Little et al., 2007; Wagner et al., 1996). The relation between plant traits defining plant functional type and competitive ability have been widely studied in many plant communities other than forests, including wetlands, grasslands and pastures (Gitay and Noble, 1997; Goldberg, 1996; Lavorel and Garnier, 2002). However, there has been little research on plant-tree interactions in forests focusing on mechanisms of competition and competitive ability among various functional groups of herbaceous plants. Some plant traits such as the leaf mass on an area basis (LMA) or the specific root length (SRL, the length of root divided by their mass) have been proved to be relatively good indicator of plant resource acquisition and use or of growth performance (Garnier et al., 2001; Roumet et al., 2006). For example it has been shown that $S R L$ is efficient for characterizing the soil exploitation strategy of forest tree species (Curt and Prévosto, 2003) and LMA could reflect conditions of sapling irradiance but also water and nutrient supply (Prévosto and Balandier, 2007).

This study focused on competition between European beech saplings (Fagus sylvatica) and vegetation in plantations. European beech is a major broad-leaved species found in the forests of central and Western Europe. Beech is considered a shade-tolerant species (Ellenberg, 1988), but many studies have demonstrated that below-ground competition from neighboring vegetation is the main factor impeding beech growth under moderate or full light conditions (Coll et al., 2003; Löf, 2000). On mesic soils in the French Massif Central, two main vegetation types can rapidly colonize large gaps in forest or open area; grasses (Graminoids), which have proved their capacity to out-compete young crop trees for water and nutrients (Coll et al., 2004; Collet et al., 1996; Davies, 1987), and dense pure thickets of small shrubs such as scotch broom (Cytisus scoparius, Gaudio et al., 2008). In Europe, broom is not considered a potential threat because it is native and it was a component of agricultural activity in the 19th century (Prévosto et al., 2004). However, Smith and Harlen (1991) have demonstrated that broom prevents the recruitment of overstory species. These two groups of species, graminoids and tall shrubs, present very different morphologies and growth dynamics (Balandier et al., 2006). Grass species often rapidly develop a dense fasciculate root system in early spring (Balandier et al., 2008), while broom grows tall over a long continuous growth period (Fogarty and Facelli, 1999).

The objective of this study was to evaluate and compare the interactions (above- and below-ground) between beech saplings and two weed types, grasses and broom, in natural conditions. We hypothesized that (i) grasses would have a much more harmful effect than broom on beech growth through strong competition for soil water and nitrogen, and (ii) broom would be more favorable to beech growth through a positive balance between a negative effect, i.e., competition for water and light and, as a legume species, a positive effect on nitrogen supply. Many studies estimated weed competitiveness indirectly by recording a posteriori crop tree growth and survival. In this study we investigated directly how grasses and broom modified resources (nutrient, water and light) around beech saplings, and studied the consequences of these resource variations for beech growth and functioning. We measured sapling xylem and leaf water potentials as an evaluation of water stress and leaf nitrogen content as an assessment of nitrogen availability and photosynthetic capacities. We also tested whether functional traits, $L M A$ and $S R L$, are integrated information on tree functioning.

\section{MATERIALS AND METHODS}

\subsection{Study area and experimental site}

The study area was a mid-elevation granite mountain range (Combrailles, mean $700 \mathrm{~m}$ a. s. 1.) in the French Massif central (Balandier et al., 2005). The climate was mountainous with oceanic influences (mean annual rainfall $850 \mathrm{~mm}$, and average temperature $9{ }^{\circ} \mathrm{C}$ ). The experimental site $\left(45^{\circ} 98 \mathrm{~N}, 2^{\circ} 65 \mathrm{E}\right)$ was a former 2.5 ha 30 -year-old stand of Norway spruce (Picea abies) felled following a windthrow in 1999. Before experiment installation in summer 2002, coarse debris had been cleared into E-W orientated windrows spaced approximately $30 \mathrm{~m}$ apart. Soil was brown acidic on a granite substrate $\left(\mathrm{pH}_{\mathrm{water}}=4.6\right)$. This soil had a sandy silt texture and contained a high proportion of coarse sand. Water retention is low in this type of soil, and wilting point was estimated from the texture to correspond to a volumetric soil water content of about 5\% (Baize and Jabiol, 1995).

\subsection{Experimental design and vegetation composition}

In November 2002, 2500 two-year-old beech seedlings (Fagus sylvatica $)$ of similar size $(45.2 \pm 9.2 \mathrm{~cm}$ mean stem height and $6.2 \pm$ $1.3 \mathrm{~mm}$ mean stem basal diameter) from a local tree nursery were planted with a spacing of $2 \mathrm{~m} \times 2 \mathrm{~m}$ on the 2.5 ha area. During winter 2002 , the area was divided up into three blocks based on topography (two blocks were on a small slope, less than $10 \%$, whereas the third one was on a flat surface), and soil analysis (one block was slightly less fertile than the other two). In each block, 100 saplings were annually weeded to maintain a "bare soil" control without vegetation.

In 2003 and 2004, vegetation composition and each species' abundance/dominance (Braun Blanquet coefficient) were assessed in June inside a $1 \mathrm{~m}^{2}$ circle around the beech saplings for a total of $200 \mathrm{in}-$ dividuals randomly distributed in the three blocks. Dominating vegetation species were broom (Cytisus scoparius) and grasses (Holcus mollis, Holcus lanatus and Agrostis capillaris). In these two dominant covers, mixed compositions were found with either broom or grasses making up more than $50 \%$ and few other species significantly present $(>5 \%)$ (Linaria repens, Rumex acetosella, Digitalis purpurea). From these data, in each block we classified sampled saplings in three groups (broom, grasses and bare soil) using ascending hierarchical classification based on the closest neighbor method. Saplings surrounded by mixed vegetation were extracted from the analysis to avoid confounding effect. Making that reduced the sample to a total of 30 saplings (including 3 saplings on bare soil in each block). Experimental design was slightly unbalanced because there were no beech saplings dominated by grasses in block 1 . Data were analyzed taking this fact into account (see Sect. 2.4). 
The experiment was designed to focus on interactions between beech saplings and broom or grasses in natural conditions. We did not therefore control plant densities. Our purpose was to evaluate the competitiveness of the two species establishing themselves from the seed bank. However, both broom and grasses were probably at their maximum density in 2004, with an $8 \%$ mean light transmitted at soil level under broom for a height of $1.2 \mathrm{~m}$, and the find of some dead individuals, evidence of self-thinning in particular for broom.

\subsection{Measurements}

All the measurements considered were made on the sample of 30 beeches with the exception of trees analyzed for root system, which were harvested separately to prevent the destruction of the permanent samples.

\subsubsection{Beech sapling growth}

Stem basal diameter and total height of the 30 sampled beech saplings were measured in October every year after the plantation. To account for intra-seasonal variations in diameter growth rate, a subsample of 14 beech saplings from the previous one were equipped in 2004 with linear variable differential transformers (LVDT; Model DF2.5, Solartron Metrology, Massy, France), which gave diameter variations to an accuracy of $1 \mu \mathrm{m}$. The LVDT measurements were recorded as 15 -min means.

\subsubsection{Beech sapling water status}

Leaf predawn water potential $\left(\Psi_{\mathrm{p}}\right)$ and midday xylem water potential $\left(\Psi_{\mathrm{x}}\right)$ of the 30 beeches (same as growth measurements) were measured using a pressure chamber (Scholander et al., 1965) during a dry period in the growing season (28 July 2004). For $\Psi_{x}$ each sampled leaf was individually wrapped in aluminum foil at least $2 \mathrm{~h}$ before collection for measurement. Three leaves per tree were measured and the values averaged for $\Psi_{\mathrm{p}}$ and similarly three leaves per tree were used and the values averaged for $\Psi_{\mathrm{x}}$.

\subsubsection{Beech sapling leaf traits}

Beech leaves collected for water potential assessment were analyzed for leaf mass on an area basis ( $L M A, \mathrm{~g} \mathrm{DM} \mathrm{m}^{-2}$ ) and nitrogen content $\left(\mathrm{N}_{\mathrm{m}}, \mathrm{g} 100 \mathrm{~g} \mathrm{DM}{ }^{-1}\right)$. Fresh leaves were scanned and leaf area was computed using the Winfolia software package (Regent instruments, QC, Canada). The samples were dried at $65{ }^{\circ} \mathrm{C}$ for $96 \mathrm{~h}$. Leaves were then weighed and $L M A$ was calculated for each tree. Leaves of the same tree were combined for nitrogen analysis. Total nitrogen content was determined using a Carlo Erba analyzer (EA 1108 CHNSO, Milan, Italy). The results are averages of replicate determinations in two subsamples of the same material.

\subsubsection{Beech specific root length (SRL)}

At the end of the second growing season (2004), a separate sample of 33 saplings was manually harvested (carefully, using a pronged spade to limit root breaking) and oven-dried at $70{ }^{\circ} \mathrm{C}$ for $96 \mathrm{~h}$. Root dry weight was then determined. Fine root morphology was assessed using WinRhizo TM image analysis software V5.0A (Regent Instruments) in particular to calculate root length. Then, the specific root length $\left(S R L, \mathrm{~m} \mathrm{~g}^{-1}\right)$, i.e. the length of roots divided by their weight, was computed.

\subsubsection{Soil nitrogen content}

Total soil nitrogen $\left(\mathrm{N}_{\mathrm{s}}, \mathrm{g} \mathrm{kg}^{-1}\right)$ was determined in the three blocks at the beginning of the experiment (autumn 2002) and in May 2005 in the first soil mineral layer $(10-20 \mathrm{~cm})$. Soil samples were heated at $1000{ }^{\circ} \mathrm{C}$ in the presence of oxygen, and the $\mathrm{N}_{2}$ formed was quantified after separation by chromatography.

\subsubsection{Soil Water Content}

Volumetric soil water content $(S W C)$ was measured every two weeks with a Time Domain Reflectometry probe (Trime T3, IMKO, Ettlingen, Germany) on the 30 saplings selected for growth measurements. Measurements were made in the first $0-20 \mathrm{~cm}$ soil layer. The TDR probe used was a tube-type device designed for measurement in permanent thin-walled plastic tubes. The thin-walled tubes were driven vertically into the soil using an auger. Tubes were placed at $20 \mathrm{~cm}$ distance from each beech sapling. For each tube and date the mean of two measurements taken in two different directions was used for subsequent analysis.

\subsubsection{Light availability for saplings}

The photosynthetically active radiation transmitted $\left(P A R_{\mathrm{t}}, 400-\right.$ $700 \mathrm{~nm}$ ) by the vegetation was measured with a ceptometer (Decagon Devices, Pullman, WA, USA) on the same 30 saplings. $P A R_{\mathrm{t}}$ is the ratio of the PAR measured below the vegetation to the incident $P A R$ (above the vegetation) measured at the same time with a Licor Quantum sensor (LiCor Inc., Lincoln, Nebraska, USA). Unidirectional measurements (orientated to the sun) were made at $15 \mathrm{~cm}$ distance from the tree saplings at three vertical levels: 10 and $20 \mathrm{~cm}$ below the apex of the beech saplings and at soil level. These measurements were made once at noon during the growing season (28 July 2004).

\subsection{Data analysis}

To avoid confounding effects of the transplanting shock in 2003, only measurements made in the year 2004 were used (second year after plantation). To account for possible differences in the size of the saplings at the beginning of 2004, relative growth increment $(R G I)$ was used and calculated, for example for stem diameter $(R D I)$, as:

$$
R D I=\frac{\left(D_{i+1}-D_{i}\right)}{D_{i}}
$$

where $D_{i}$ and $D_{i+1}$ are the sapling stem basal diameter at budburst and leaf fall, respectively. To ensure that it was relevant to use $R D I$ in our experiment (South, 1995), we plotted current increment $\left(D_{i+1}-D_{i}\right)$ against $D_{i}$. Whatever the treatment considered, it was apparent (data not shown) that saplings were growing according to the same inherent growth curve. 


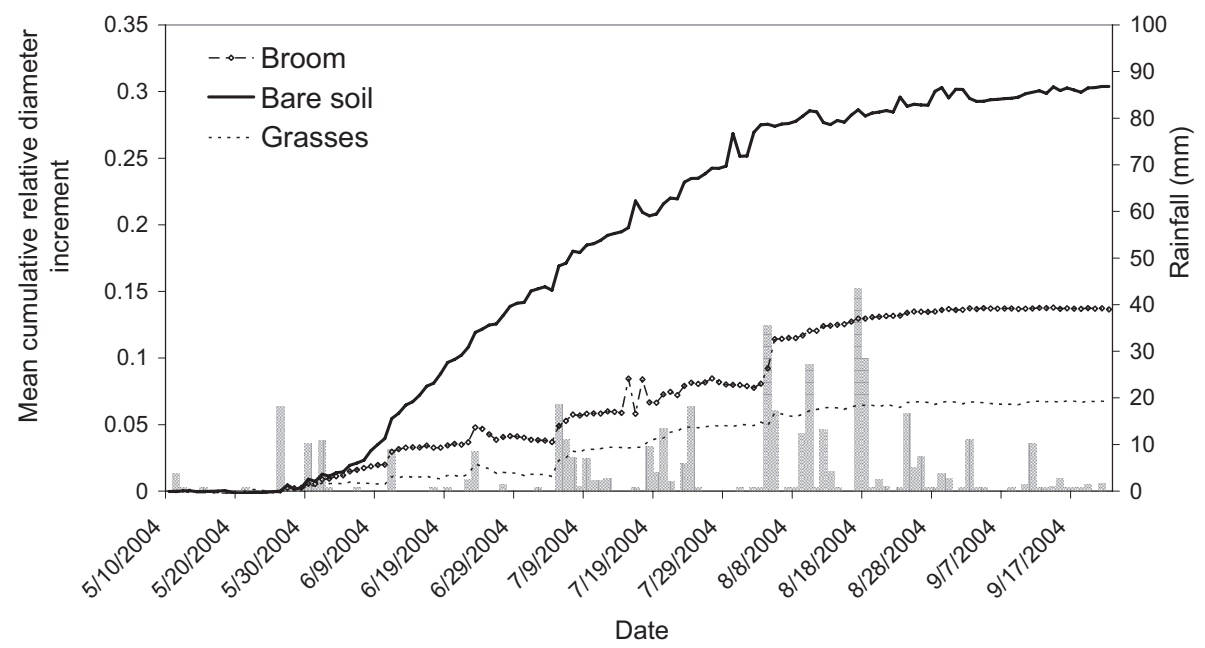

Figure 1. Mean cumulative relative diameter increment of the beech saplings in the bare soil, or surrounded by broom or grasses, measured with LVDT sensors, and daily rainfall $(\mathrm{mm})$ from May to September 2004 in a plantation of Central France.

Table I. Beech sapling growth and functional traits (mean \pm standard error) for each surrounding vegetation cover in 2004.

\begin{tabular}{|c|c|c|c|c|}
\hline & Grass & Broom & Bare Soil & $p$ value \\
\hline Height $(\mathrm{m})$ & $0.57 \pm 0.0$ & $0.60 \pm 0.02$ & $0.64 \pm 0.06$ & 0.49 \\
\hline$R H I^{a}$ & $0.135 \pm 0.058$ & $0.162 \pm 0.026$ & $0.403 \pm 0.105$ & 0.09 \\
\hline $\mathrm{N}_{\mathrm{m}}(\%)$ & $1.68 \pm 0.06 \mathrm{a}$ & $1.86 \pm 0.11 \mathrm{a}$ & $2.13 \pm 0.03 \mathrm{~b}$ & 0.03 \\
\hline$\Psi_{\mathrm{x}}(\mathrm{MPa})$ & $-2.1 \pm 0.2$ & $-1.7 \pm 0.1$ & $-1.5 \pm 0.1$ & 0.10 \\
\hline$\left|\mathrm{N}_{\mathrm{m}}: \Psi_{\mathrm{x}}\right|$ & $0.82 \pm 0.05$ & $1.14 \pm 0.14$ & $1.51 \pm 0.17$ & 0.06 \\
\hline$L M A\left(\mathrm{~g} \mathrm{~m}^{-2}\right)$ & $60.1 \pm 2.3 \mathrm{a}$ & $74.3 \pm 3.0 \mathrm{~b}$ & $80.6 \pm 0.89 \mathrm{~b}$ & 0.006 \\
\hline$S R L\left(\mathrm{~m} \mathrm{~g}^{-1}\right)$ & $18.6 \pm 2.9$ & $33.4 \pm 4.3$ & $26.2 \pm 3.8$ & 0.13 \\
\hline
\end{tabular}

a Relative height and diameter increments $(R H I$ and $R D I)$ were computed for a 2-year period.

* Values designated by different letters are significantly different at $\alpha=0.05$.

An ANOVA was used to analyze vegetation composition effect on resource availability (water, $\mathrm{N}_{\mathrm{s}}, P A R_{\mathrm{t}}$ ), beech physiological variables $\left(\Psi_{\mathrm{p}}, \Psi_{\mathrm{x}}, \mathrm{N}_{\mathrm{m}}\right)$ or beech growth $(R D I)$ and functional traits $(L M A, S R L)$ with an LSD procedure to separate means. The average of each block for the considered variable was used in analysis $(n=3$, true replications) for each of the three vegetation conditions (bare soil, grass and broom). Experimental design was slightly unbalanced because there were no beech saplings dominated by grasses in block 1 . Therefore, means resulting from the variance analysis were corrected for missing data by minimization of least-square estimates. Data were analyzed using Statgraphics Centurion XV (Statpoint Inc, Herndon, USA) software. Differences were considered significant when $p<0.05$.

\section{RESULTS}

\subsection{Beech sapling growth}

Rain was irregularly distributed throughout the season, creating some short dry periods in June, July and early August (Fig. 1). During these dry periods, beech diameter growth as measured by LVDT sensors slightly decreased (on bare soil) or almost stopped (on grass and broom). Resumed beech diameter growth was immediately recorded after rain events. At the end of the growing season neither beech sapling height nor diameter were significantly different among treatments. Differences were more marked using relative growth increment, which takes into account initial size differences; beeches on grasses and broom exhibited a significant lower RDI than on bare soil (Tab. I).

\subsection{Resource availability, beech physiological parameters and growth}

Soil nitrogen content $\left(\mathrm{N}_{\mathrm{s}}\right)$ was high at the beginning of the experiment and increased during the experiment for all three vegetation covers, particularly on bare soil (Tab. II). Soil water content $(S W C)$ computed at the growing season scale was slightly higher on bare soil (Tab. II). The photosynthetically active radiation $\left(P A R_{\mathrm{t}}\right)$ transmitted at $10 \mathrm{~cm}$ (Tab. II) and $20 \mathrm{~cm}$ below the beech apex, and at ground level were significantly different on broom and on bare soil, grasses being intermediate $\left(p=0.04, p=0.0027 ; p=0.0008\right.$ for $P A R_{\mathrm{t}}$ at $10 \mathrm{~cm}$ and $20 \mathrm{~cm}$ below the beech apex and at ground level, respectively). 
Table II. Beech resource availability in each surrounding vegetation cover.

\begin{tabular}{lccccc}
\hline Year & $\begin{array}{c}\text { Whole } \\
\text { site }\end{array}$ & Grass & Broom & Bare soil & $p$ value \\
\hline $\begin{array}{l}\mathrm{N}_{\mathrm{s}} 2002 \\
\left(\mathrm{~g} \mathrm{~kg}^{-1}\right)\end{array}$ & 2.03 & & & & \\
$\mathrm{~N}_{\mathrm{s}} 2005$ & & 3.73 & 2.52 & 5.14 & \\
$\left(\mathrm{~g} \mathrm{~kg}^{-1}\right)$ & & & & \\
$S W C(\%)$ & & $11.4 \pm 1.5 \mathrm{a}^{*}$ & $11.2 \pm 0.3 \mathrm{a}$ & $14.3 \pm 0.6 \mathrm{~b}$ & 0.05 \\
$P A R_{\mathrm{t}}$ & & $0.90 \pm 0.07 \mathrm{~b}$ & $0.70 \pm 0.07 \mathrm{a}$ & $0.96 \pm 0.006 \mathrm{c}$ & 0.04 \\
\hline
\end{tabular}

${ }^{\text {a }}$ Soil total nitrogen content $\left(\mathrm{N}_{\mathrm{s}}\right)$ in the 10-20 cm layer was measured for the whole site at planting date (autumn 2002) and under different vegetation covers in May 2005 (no replication).

* Values (mean $\pm \mathrm{SE}$ ) for volumetric soil water content $(S W C)$ averaged for the 2004 growing season in the 0-20 cm layer and transmitted PAR $\left(P A R_{\mathrm{t}}\right) 10 \mathrm{~cm}$ below beech apex in July 2004 are different when designated by different letters at $\alpha=0.05$.

Beech leaf nitrogen content $\left(\mathrm{N}_{\mathrm{m}}\right)$ was significantly higher on bare soil (Tab. I). Beech xylem water potential $\left(\Psi_{\mathrm{x}}\right)$ tended to be lower on grasses than on bare soil, while beech $\Psi_{x}$ on broom was intermediate, though differences were not significant at $\alpha=0.05$ (Tab. I). No significant difference was recorded for beech leaf predawn water potential $\left(\Psi_{\mathrm{p}}\right)$ between the different vegetation covers. The ratio $\left|\mathrm{N}_{\mathrm{m}}: \Psi_{\mathrm{x}}\right|$ was significantly higher on bare soil than on grasses at $\alpha=0.06$.

There were no clear relationships between beech $R D I$ and $P A R_{t}$ at any level $(10 \mathrm{~cm}$ or $20 \mathrm{~cm}$ below beech apex, or at ground level), with the bare soil giving a significantly higher beech $R D I$ for similar light value as on grasses (Fig. 2a). Similarly, beech $R D I$ did not show a clear relationships with SWC in the $0-20 \mathrm{~cm}$ interval $\left(R^{2}=0.46\right)$, the bare soil showing the highest values of $R D I$ and $S W C$ (Fig. 2b). Conversely, beech $R D I$ was negatively correlated with $\left|\Psi_{\mathrm{x}}\right|\left(R^{2}=0.70, p=0.009\right.$, Fig. 2c), and positively with $\mathrm{N}_{\mathrm{m}}\left(R^{2}=0.54, p=0.04\right.$, Fig. $\left.2 \mathrm{~d}\right)$, and with the ratio $\left|\mathrm{N}_{\mathrm{m}}: \Psi_{\mathrm{x}}\right|\left(R^{2}=0.69, p=0.01\right.$, Fig. 2e).

\subsection{Beech leaf attributes and nitrogen, water potential and light}

Beech leaves were significantly smaller $(p=0.01)$ and lighter $(p=0.009)$ on grasses than on either broom or bare soil (Tab. I). Leaf mass on an area basis (LMA) of beech on grasses was significantly smaller than on broom or on bare soil ( $p=0.006$, Tab. I). There was no clear relationship between beech $L M A$ and $P A R_{\mathrm{t}}$ (Fig. 3a), while $L M A$ was negatively correlated with beech $\left|\Psi_{\mathrm{x}}\right|\left(R^{2}=0.76, p=0.005\right.$, Fig. 3b), and positively with $\mathrm{N}_{\mathrm{m}}\left(R^{2}=0.51, p=0.05\right.$, Fig. $\left.3 \mathrm{c}\right)$, and $\left|\mathrm{N}_{\mathrm{m}}: \Psi_{\mathrm{x}}\right|$ $\left(R^{2}=0.74, p=0.006\right.$, Fig. 3d $)$.

\subsection{Beech relative diameter increment versus functional traits}

No statistical difference was detected between beech specific root length (SRL, Tab. I) and there was also no clear relationship between beech $R D I$ and $S R L$ (Fig. 4a). In contrast, beech $R D I$ was clearly positively correlated with beech $L M A$ $\left(R^{2}=0.91, p=0.0002\right.$, Fig. $\left.4 \mathrm{~b}\right)$.

\section{DISCUSSION}

\subsection{Effect of vegetation on resource depletion and beech sapling growth}

In the absence of competition, beech saplings on bare soil showed rapid development, but when vegetation was present, particularly grasses, beech sapling growth was strongly reduced, as frequently reported (e.g. Collet et al., 1996). Beech leaf nitrogen content $\left(\mathrm{N}_{\mathrm{m}} \%\right)$ was significantly lower when surrounded by grasses than on bare soil, and midday xylem water potential $\left(\Psi_{\mathrm{x}}\right)$ tended to be more negative with grasses, confirming previous studies demonstrating that weeds and especially grass competition affect mainly below-ground resources (Coll et al., 2004; Hangs et al., 2002).

Reduction of beech growth induced by broom cover was also significant compared with bare soil. $\mathrm{N}_{\mathrm{m}}$ and $\Psi_{\mathrm{x}}$ values tended to be higher for beech saplings on broom than on grasses though differences were not significant at $\alpha=0.05$. Watt et al. (2003b) suggested that the presence of broom, owing to its nitrogen-fixing ability, may enhance the long-term growth of Pinus radiata on watered, nitrogen-deficient sites. However in this study soil nitrogen was not deficient, particularly in the bare soil, probably owing to intense mineralization following the setting-up of the experiment. Values of soil and leaf nitrogen content (higher than 1.5\%, the critical threshold for beech following Bonneau, (1986)) indicate that nitrogen was not a limiting factor in the growth of beech saplings in our conditions.

Broom grows faster than most forest tree saplings and it can create a very dense light-intercepting canopy. Smith and Arlen (1991) considered that broom could stop regeneration from overstorey species. In our experiment, the transmitted PAR $\left(P A R_{\mathrm{t}}\right)$ at $10 \mathrm{~cm}$ below the apex of the beech sapling was in mean never less than $70 \%$ and still over $40 \%$ at $20 \mathrm{~cm}$ below beech apex. Given that beech is shade-tolerant, this light level is considered sufficient to support a high beech growth rate (Balandier et al., 2007; Coll et al., 2003), even in the case we consider a slight decrease of light availability with little taller brooms in the next years. Consequently, light availability did not seem to have dramatically affected beech growth in our conditions.

Volumetric soil water content under broom and grasses was lower throughout the season than in the bare soil but never reached the wilting point (5\% soil water content (Baize and Jabiol, 1995), suggesting that water was still available for the tree, though not in great amounts. The absence of any difference for the leaf predawn water potential $\left(\Psi_{\mathrm{p}}\right)$ between the different vegetation conditions may have reflected this. However, broom $\Psi_{\mathrm{x}}$ tended to be higher than those of grass, at least in two blocks (Fig. 2c), suggesting that beech water stress would have been less marked on broom during the day. Thus the presence of broom may have a favorable effect on beech water status. Considering the moderate light interception by broom, we 


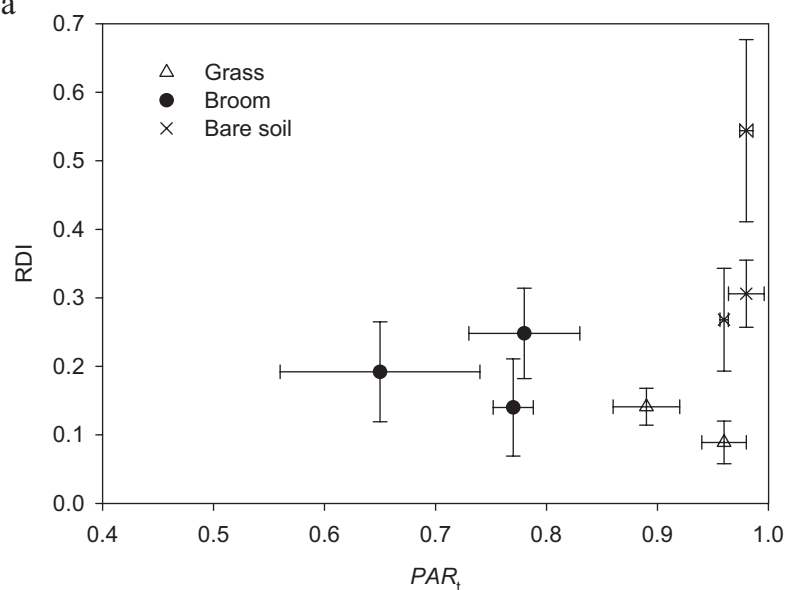

b

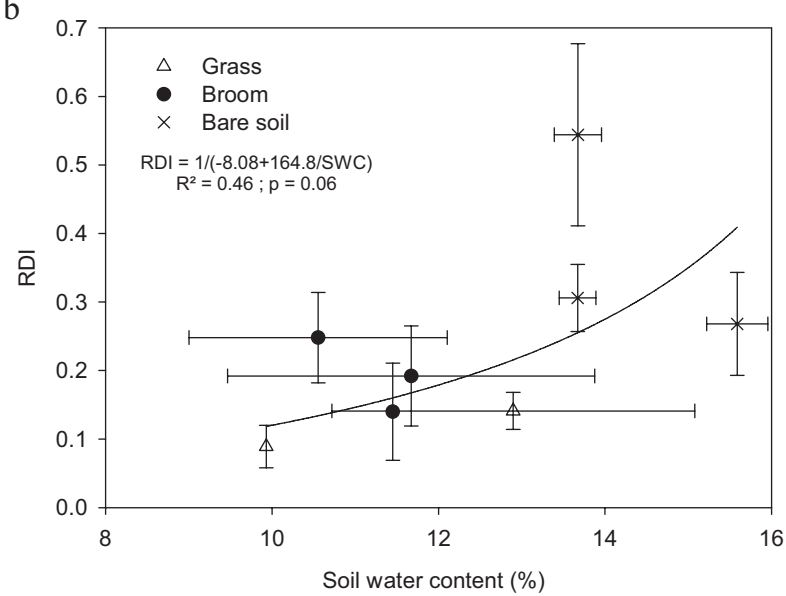

$\mathrm{c}$

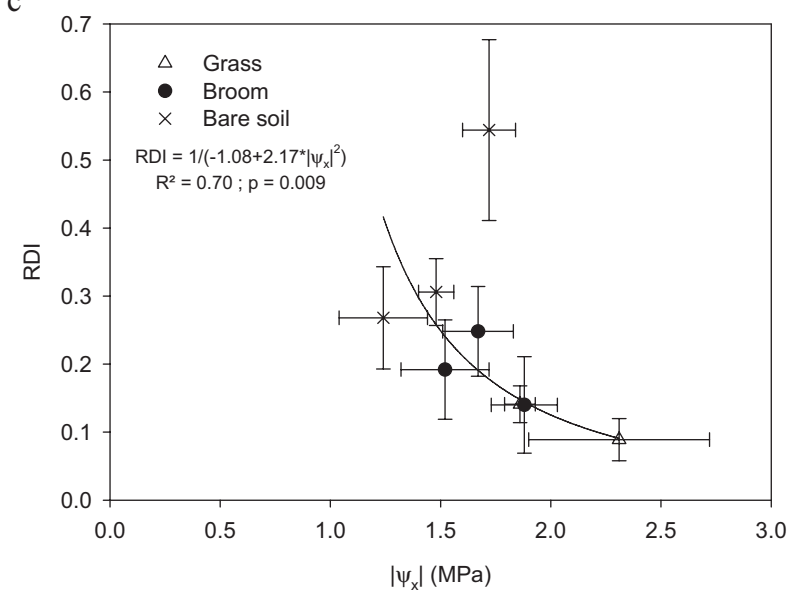

d

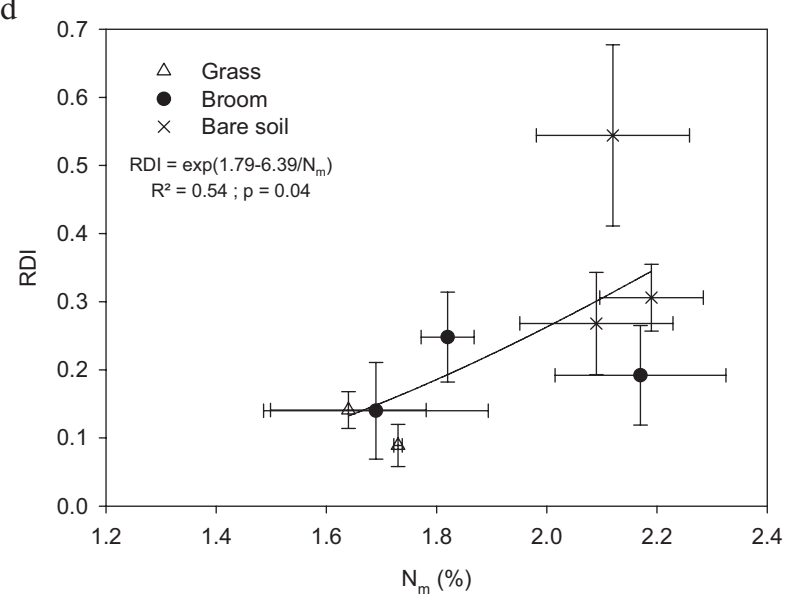

e

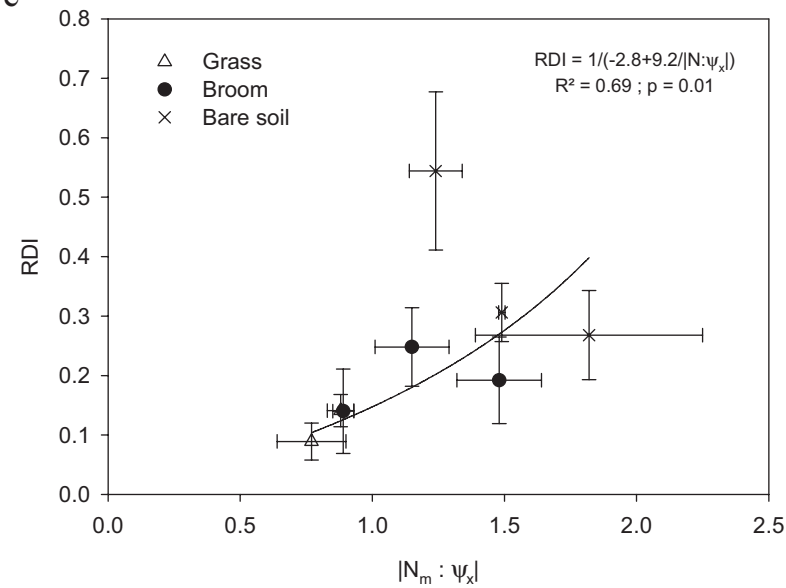

Figure 2. Beech sapling relative diameter increment $(R D I)$ relative to transmitted $P A R$ at $10 \mathrm{~cm}$ below beech apex $\left(P A R_{\mathrm{t}}, 2 \mathrm{a}\right)$, volumetric soil water content averaged for the 2004 growing period (2b), beech xylem water potential ( $\Psi_{\mathrm{x}}$, MPa, absolute value, 2c), beech leaf nitrogen content on a mass basis $\left(\mathrm{N}_{\mathrm{m}}, \mathrm{g} 100 \mathrm{~g} \mathrm{DM}^{-1}, 2 \mathrm{~d}\right)$, and ratio $\mathrm{N}: \Psi_{\mathrm{x}}$ (absolute value, 2e). Each point corresponds to the mean ( \pm standard error) of a type of vegetation (grass, broom, bare soil) and a block. The best fitting curve and corresponding $R^{2}$ and $p$ values are given when significant. Beeches were planted at the autumn 2002 in Central France. 
a

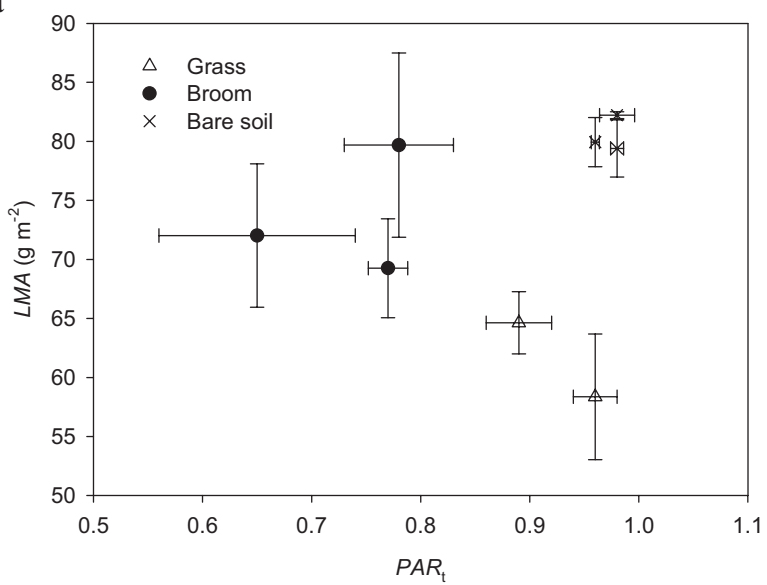

b

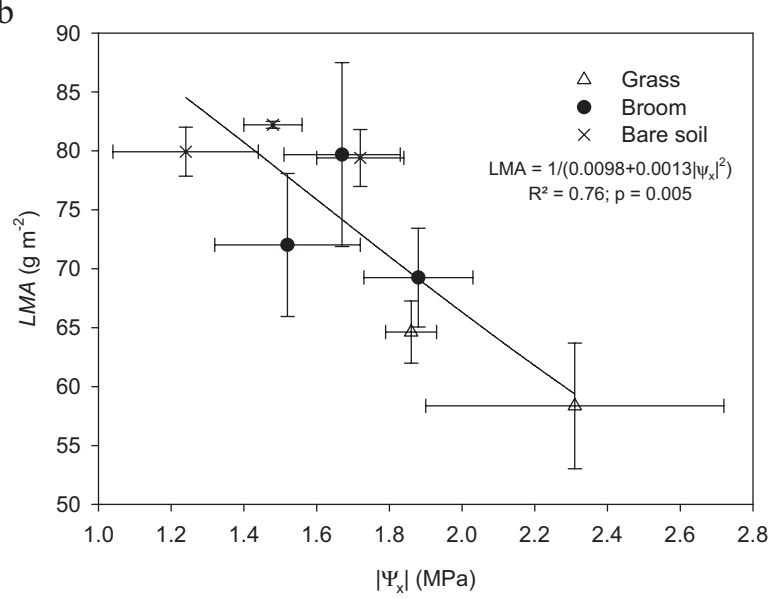

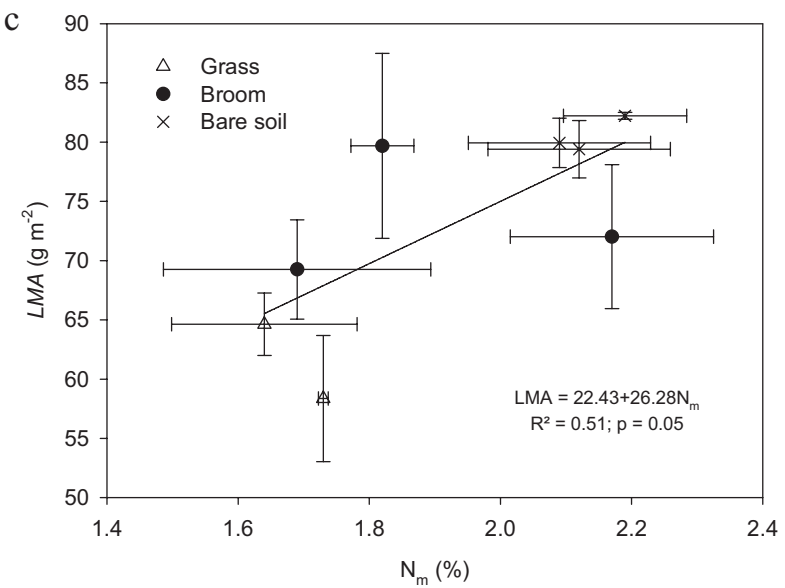

d

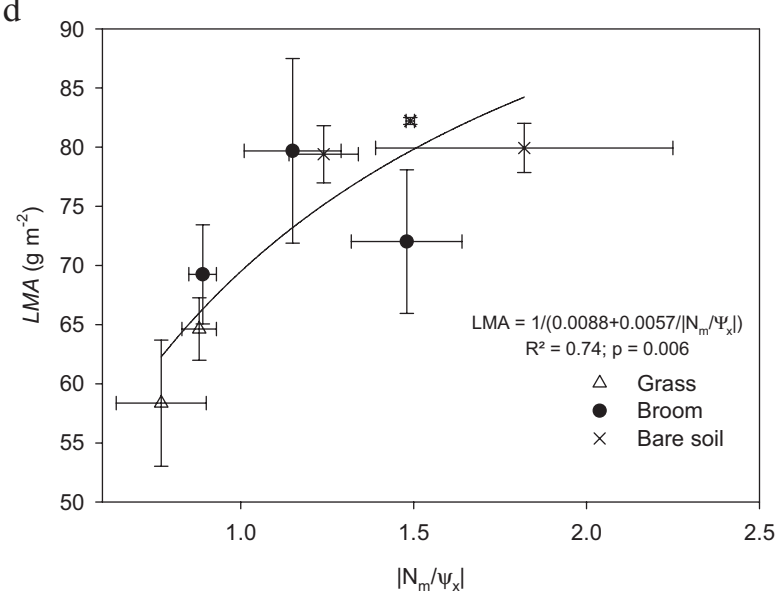

Figure 3. Beech sapling leaf mass on an area basis $\left(L M A, \mathrm{~g} \mathrm{~m}^{-2}\right)$ relative to transmitted PAR at $10 \mathrm{~cm}$ below beech apex $\left(P A R_{\mathrm{t}}, 3 \mathrm{a}\right)$, beech leaf nitrogen content on a mass basis $\left(\mathrm{N}_{\mathrm{m}}, \mathrm{g} 100 \mathrm{~g} \mathrm{DM}{ }^{-1}, 3 \mathrm{c}\right)$, beech xylem water potential $\left(\Psi_{\mathrm{x}}, \mathrm{MPa}\right.$, absolute value, $\left.3 \mathrm{~b}\right)$, and ratio $\mathrm{N}: \Psi_{\mathrm{x}}$ (absolute value, 3d). Each point corresponds to the mean ( \pm standard error) of a type of vegetation (grass, broom, bare soil) and a block. The best fitting curve and corresponding $R^{2}$ and $p$ values are given when significant. Beeches were planted at the autumn 2002 in Central France.

can hypothesize that broom created a favorable microclimate for beech growth, i.e. a reduction of potential evapotranspiration while allowing a sufficient photosynthesis rate.

Therefore the better leaf nitrogen content found for saplings on bare soil, and to a lesser extent on broom in two blocks (Fig. 2d), may have mainly resulted from a better uptake of nitrogen than on grasses due to less unfavorable water status. This hypothesis is strongly supported by the significant variation in the beech sapling $\left|\mathrm{N}: \Psi_{\mathrm{x}}\right|$ ratio among the different vegetation covers (Fig. 2e). This ratio expresses the dependency of $\mathrm{N}$ uptake on water availability, i.e., nitrogen uptake per unit water availability (De Montard et al., 1999). This ratio was significantly twice as high on bare soil as on grasses.

\subsection{Beech sapling functional traits as competition indicators}

Leaf mass on an area basis ( $L M A$, or its reciprocal, specific leaf area, SLA) is reported to be one of the most sensitive and integrative measures of the degree of stress experienced by a tree (Nambiar and Sands, 1993). Following other studies (e.g., Curt et al., 2005) we found that beech $R D I$ was very significantly correlated with $L M A\left(R^{2}=0.91, p=0.0002\right)$, and that $L M A$ was significantly correlated with both water and nitrogen ( $R^{2}=0.76$ and 0.51 , respectively). The grass cover induced the lowest beech $L M A$ concomitant with the lowest $R D I$. Conversely, beeches on bare soil displayed the highest $L M A$ and the highest $R D I$. In most of the literature, for plastic species, a high $L M A$ is interpreted as an increase in the intercepting surface for the same dry matter weight when light is reduced (King, 2003). In our case, without ruling out a light effect of this sort for beeches on broom, beech displayed smaller and especially lighter leaves in the presence of grasses. It has been shown that limitation by water or nitrogen results in smaller cells and smaller leaves (Loomis, 1997).

The results were not so clear for beech specific root length $(S R L)$. Fine root morphology (i.e. higher $S R L)$ often adapts rapidly to water and (or) nutrient depletion in relation to 
a

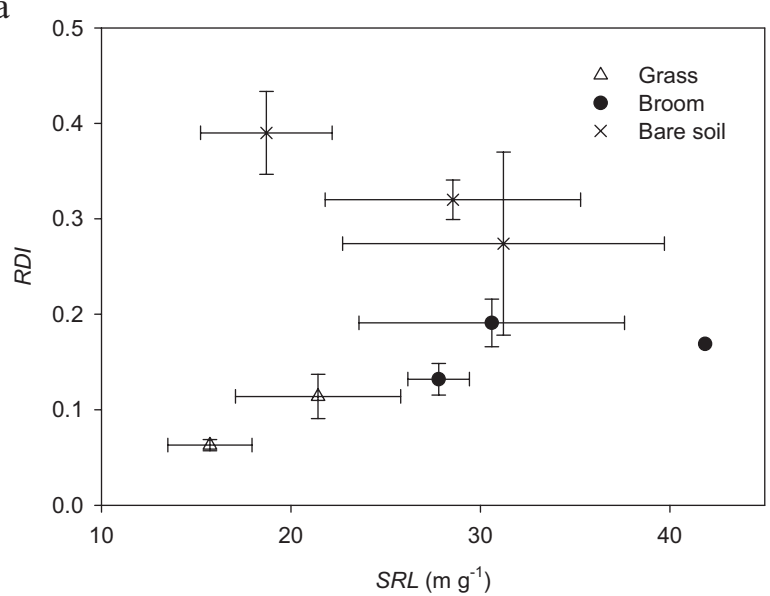

b

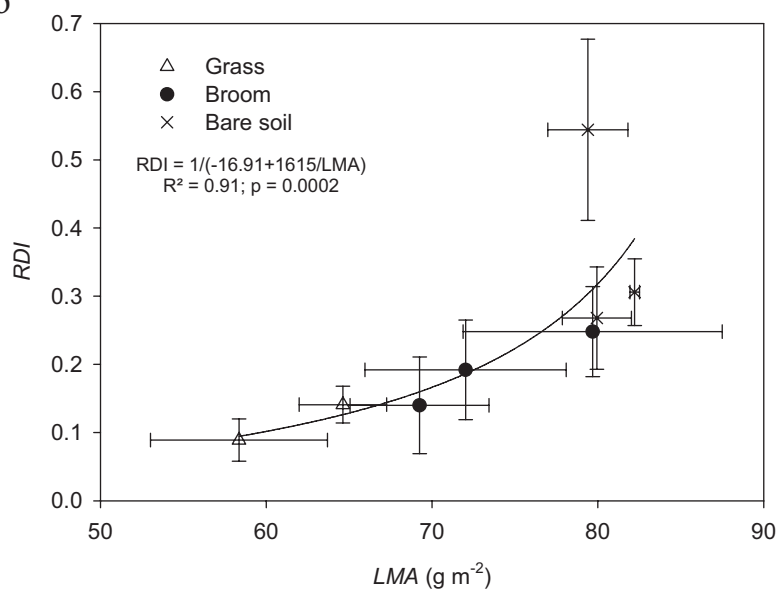

Figure 4. Beech sapling relative diameter increment $(R D I)$ relative to beech specific root length $\left(S R L, \mathrm{~m} \mathrm{~g}^{-1}, 4 \mathrm{a}\right)$, and beech leaf mass on an area basis $\left(L M A, \mathrm{~g} \mathrm{~m}^{-2}\right)$. Each point corresponds to the mean ( \pm standard error) of a type of vegetation (grass, broom, bare soil) and a block. The best fitting curve and corresponding $R^{2}$ and $p$ values are given when significant. Beeches were planted at the autumn 2002 in Central France.

competition intensity by the herbaceous layer (Callaway and Mahall, 1996; Curt et al., 2005). Surprisingly, we did not record significant variations in $S R L$ among vegetation covers, although we were expecting a higher $S R L$ for beech on grasses. One hypothesis is that the very dense structure of the grass root system in the upper soil layer (Balandier et al., 2008) inhibited beech root elongation. This hypothesis has already been discussed by McConnaughay and Bazzaz (1991), but with plants in pots of different sizes. Plant strategy in adapting to limited space availability seems species-dependent, and the interactions with nutrients or water availability complicate the interpretation.

\subsection{Conclusion: implications for forest vegetation management}

Although chemical treatment (bare soil) remains the most favorable treatment for beech establishment and growth in plantations, identifying the type of plant competitors facing the forest manager could allow management strategies that are more environmentally sound or closer to natural conditions (opportunistic sensu Schütz, 2004). Balandier et al. proposed in 2006 a classification of the vegetation commonly competing with trees in five groups: graminoids, forbs (herbaceous dicotyledons), small shrubs, large shrubs and midstorey trees, and main storey trees. Plant species within a group are generally considered as following similar temporal patterns of competitiveness against crop trees. In this classification, grasses are strong competitors for water and nutrients at the expense of tree saplings as recorded in this study, and forest managers should systematically monitor the development of this enemy. Effective vegetation management can be achieved using herbicides or, when possible, using artificial or natural shelterwood that prevents the installation of grasses by shading.

As sometimes reported in France (e.g., Boulet-Gercourt et al., 2002) broom can be an ally by sheltering and protecting beech saplings, thus reducing transpiration. Some of the results in this study seem to corroborate such an observation, whereas they would require to be confirmed. Also, the shade created by the broom can prevent the development of the more competing light-requiring grasses as we recorded a negative correlation between broom and grass abundance (data not shown). Therefore broom can be properly managed by cutting out broom stems that overhang the tree saplings' main shoot. However, caution is required as broom can be a strong competitor outside the geographic range of beech (Bossard, 1991; Smith and Harlen, 1991; Watt et al., 2003a).

Acknowledgements: We are grateful to Fabrice Landré, André Marquier, Rolland Paillat, René Jouvie and Monique Bouchaud for their valuable technical assistance in the field. We also thank Henri Frochot and Lluis Coll for their helpful discussions and comments on the first draft. This research was partly funded by the Regional Directorate of Agriculture and Forests (Auvergne) and the European Community (FEOGA).

\section{REFERENCES}

Baize D. and Jabiol B., 1995. Guide pour la description des sols, INRA, Paris, $375 \mathrm{p}$.

Balandier P., Guitton J.L., and Prévosto B., 2005. Forest restoration in the French Massif Central mountains. In: Stanturf J. and Madsen P. (Eds.), Restoration of Boreal and Temperate Forests, CRC Press, Boca Raton, USA, pp. 355-369.

Balandier P., Collet C., Miller J.H., Reynolds P.E., and Zedaker S.M., 2006. Designing forest vegetation management strategies based on the mechanisms and dynamics of crop tree competition by neighboring vegetation. Forestry 79: 3-27.

Balandier P., Sinoquet H., Frak E., Giuliani R., Vandame M., Descamps S., Coll L., Adam B., Prévosto B., and Curt T., 2007. Six-year evolution of light use efficiency, carbon gain and growth of beech saplings (Fagus sylvatica L.) planted under Scots pine (Pinus sylvestris L.) shelterwood. Tree Physiol. 27: 1073-1082.

Balandier P., De Montard F.X., and Curt T., 2008. Root competition for water between trees and grass in a silvopastoral plot of ten-yearold Prunus avium. In: Batish D.R., Kohli R.K., Jose S., and Singh H.P. (Eds), Ecological basis of agroforestry, CRC Press, Boca Raton, USA, pp. 253-270. 
Bonneau M., 1986. Fertilisation à la plantation. Rev. For. Fr. 38: 293-300.

Boulet-Gercourt B., Castana P. and Chartier M., 2002. De l'intérêt de l'accompagnement ligneux pour limiter les dégâts du chevreuil. Forêt - Entreprise 144 : 57-61.

Bossard C.C., 1991. The role of habitat disturbance, seed predation, and ant dispersal on establishment of the exotic shrub Cytisus scoparius in California. Am. Midl. Nat. 126: 1-3.

Callaway R.M. and Mahall B.E., 1996. Variation in leaf structure and function in Quercus douglasii trees differing in root architecture and drought history. Int. J. Plant. Sci. 157: 129-135.

Coll L., Balandier P., Picon-Cochard C., Prévosto B., and Curt T., 2003. Competition for water and light between beech seedlings and the surrounding vegetation in abandoned pastures colonized by woody species. Ann. For. Sci. 60: 593-600.

Coll L., Balandier P., and Picon-Cochard C., 2004. Morphological and physiological responses of beech (Fagus sylvatica) seedlings to grass-induced belowground competition. Tree Physiol. 24: 45-54.

Coll L., Messier C., Delagrange S., and Berninger F., 2007. Growth, allocation and leaf gas exchanges of hybrid poplar plants in their establishment phase on previously forested sites: effect of different vegetation management techniques. Ann. For. Sci. 64:275-285.

Collet C., Frochot H., and Guehl J.M., 1996. Growth dynamics and water uptake of two forest grasses differing in their growth strategy and potentially competing with forest seedlings. Can. J. Bot. 74: 15551561.

Curt T. and Prévosto B., 2003. Root biomass and rooting profile of naturally regenerated beech in mid-elevation Scots pine woodlands. Plant Ecol. 167: 269-282.

Curt T., Coll L., Prévosto B., and Balandier P., 2005. Growth, allocational flexibility and root morphological plasticity of beech seedlings in relation to light and herbaceous competition. Ann. For. Sci. 62: 51-60.

Davies R.J., 1987. Weed control for successful tree establishment. In: Trees and weeds, Forestry commission - Handbook, HMSO Publications, London, pp. 2-36.

De Montard F.X., Balandier P., Rapey H., Lucot F., and Drouot J.P., 1999. Compétition pour l'azote entre arbre et herbe dans des plantations de noisetier (Corylus avellana L.) et de merisier (Prunus avium L.). In: Caillez F. and Lecomte E. (Eds.), Bois et Forêts des Agriculteurs, Cemagref, Antony, France, pp. 73-94.

Ellenberg H., 1988. Vegetation ecology of Central Europe, Cambridge University Press, Cambridge, 731 p.

Fogarty G. and Facelli J.M., 1999. Growth and competition of Cytisus scoparius, an invasive shrub, and Australian native shrub. Plant Ecol. 144: 27-35.

Garnier E., Laurent G., Bellmann A., Debain S., Berthelier P., Ducout B., Roumet C., and Navs M.L., 2001. Consistency of species ranking based on functional leaf traits. New Phytol. 152: 69-83.

Gaudio N., Balandier P., and Marquier, 2008. Light-dependent development of two competitive species (Rubus idaeus, Cytisus scoparius) colonizing gaps in temperate forest. Ann. For. Sci. 65: 104.

Gitay H. and Noble I.R., 1997. What are functional types and how should we seek them? In: Smith T.M., Shugart H.H., and Woodward F.I. (Eds.), Plant functional types, Cambridge University Press, Cambridge, UK, pp. 3-19.

Goldberg D.E., 1996. Competitive ability: definitions, contingency and correlated traits. Phil. Trans. R. Soc. Lond. B 351: 1377-1385.

Hangs R.D., Knight J.D., and Van Rees C.J., 2002. Interspecific competition for nitrogen between successional species and planted white spruce and jack pine seedlings. Can. J. For. Res. 32: 1813-1821.

King D.A., 2003. Allocation of above-ground growth is related to light in temperate deciduous saplings. Funct. Ecol. 17: 482-488.
Lamhaledi M.S., Bernier P.Y., Hebert C., and Jobidon R., 1998. Physiological and growth responses of three sizes of containerized Picea mariana seedlings outplanted with and without vegetation control. For. Ecol. Manage. 110: 13-23.

Lavorel S. and Garnier E., 2002. Predicting changes in community composition and ecosystem functioning from plant traits: revisiting the Holy Grail. Funct. Ecol. 16: 545-556.

Little K.M., Rolando C.A., and Morris C.D., 2007. An integrated analysis of 33 Eucalyptus trials linking the onset of competition-induced tree growth suppression with management, physiographic and climatic factors. Ann. For. Sci. 64: 585-678.

Löf M., 2000. Establishment and growth in seedlings of Fagus sylvatica and Quercus robur: influence of interference from herbaceous vegetation. Can. J. For. Res. 30: 855-864.

Loomis R.S., 1997. On the utility of nitrogen in leaves. Proc. Natl. Acad. Sci. USA 94: 13378-13379.

McConnaughay K.D.M. and Bazzaz F.A., 1991. Is physical space a soil resource? Ecology 72: 94-103.

Nambiar E.K.S. and Sands R., 1993. Competition for water and nutrients in forests. Can. J. For. Res. 23: 1955-1968.

Prévosto B. and Balandier P., 2007. Influence of nurse birch and Scots pine seedlings on early aerial development of European beech seedlings in an open-field plantation of Central France. Forestry 80: 253-264.

Prévosto B., Robert A., and Coquillard P., 2004. Development of Cytisus scoparius $\mathrm{L}$. at stand and individual level in a mid-elevation mountain of the French Massif central. Acta Oecol. 35: 73-81.

Roumet C., Urcelay C., and Diaz S., 2006. Suites of traits differ between annual and perennial species growing in the field. New Phytol. 170: 357-368.

Scholander P.F., Hammel H.T., Bradstreet E.D., and Hemmingsen E.A., 1965. Sap pressure in vascular plants. Science 148: 339-346.

Schütz J.P., 2004. Opportunistic methods of controlling vegetation, inspired by natural plant succession dynamics with special reference to natural outmixing tendencies in a gap regeneration. Ann. For. Sci. 61: $149-156$.

Smith J.M.B. and Harlen R.L., 1991. Preliminary observations on the seed dynamics of broom (Cytisus Scoparius) at Barrington Tops, New South Wales. Plant Protection Quarterly 6: 73-78.

South D.B., 1995. Relative growth rates: A critique. S. Afr. For. J. 173: 43-48.

Wagner R.G., Noland T.L., and Mohammed G.H., 1996. Timing and duration of herbaceous vegetation control around four northern coniferous species. N. Z. J. For. Sci. 26: 39-52.

Wagner R.G., Little K., Richardson B., and Mcnabb K., 2006. The role of vegetation management for enhancing productivity of the world's forests. Forestry 79: 57-79.

Wang G.G., Su J., and Wang J.R., 2000. Height growth of planted black spruce seedlings in response to interspecific vegetation competition: a comparison of four competition measures at two measuring positions. Can. J. For. Res. 30: 573-579.

Watt M.S., Whitehead D., Mason E.G., Richardson B., and Kimberley M., 2003a. The influence of weeds on allocation and above-ground biomass growth of young Pinus radiata growing at a dryland site. For. Ecol. Manage. 183: 363-376.

Watt M.S., Clinton P.W., Whitehead D., Richardson B., Mason E.G., and Leckie A.C., 2003b. Above-ground biomass accumulation and nitrogen fixation of broom (Cytisus scoparius L.) growing with juvenile Pinus radiata on a dryland site. For. Ecol. Manage. 184: 93-104.

Willoughby I., 1999. Future alternatives to the use of herbicides in British forestry. Can. J. For. Res. 29: 866-874 